\title{
THE BELL OF FLIES ${ }^{1}$
}

"We don't say what we think. We don't do what we say."

\author{
Ruud H.C. Meij (The Netherlands) \\ Governance \& Integrity \\ University of Humanistic Studies
}

\begin{abstract}
Fighting corruption is world wide a main issue. At stake is the human right on a decent state, rule of law and accountable government. In my paper I focus on our struggle to curb corruption in one of the major cities of Ukraine, Lviv. In that I highlight the unexpected power of moral learning as a critical leverage to curb corruption. In fighting corruption it makes sense to distinguish between high level and low level, survival corruption, in Russian called Blat. Survival corruption requires a »corrupted « mind: a strategy of moral learning of civil servants. This is not the mind of a malicious, greedy or corrupt civil servant, but a moral strategy to accommodate to (post) totalitarian and oligarchic political institutionalizing in Ukraine. The tragedy of the »corrupted « mind is that it not only helps to survive conditions of corrupt oligarchic political institutions, but also tend to reproduce them. Installing a process of moral learning to deconstruct the Ukrainian, Lvivian moral narrative, and design an alternative moral discourse with civil servants, seems therefore paramount.

Based on seminars on moral learning with about 1500 civil servants in Lviv I first reconstruct this »corrupted « mind as a set of imperatives of organizational moral learning in Lviv City Council. Second I show that these imperatives are path dependent on three critical junctures of political institutionalizing in Lviv: totalitarian, oligarchic and national-democratic. In the 'oligarchic democracy', as Ukraine is called, the experience with totalitarianism still has its hold on the mind of the civil servant, although the totalitarian political institutions in itself no longer exist. This is reflected in the defensive moral reasoning shown in the »corrupted « mind, which I call the Bell of Flies. The thin and selfish morality of the oligarchic path leads only to further delegitimizing and erosion of trust in political institutions in contemporary Ukraine and Lviv, and a possible increase of low level and high level corruption. This makes plausible that breaking this spell of the Bell of Flies, and developing an alternative account of moral learning is crucial for lowering corruption and creating a decent local city administration, rule of law, and accountable City Council.

The national-democratic path, going back to the Ukrainian independence in 1991, the Orange Revolution of 2004, and the Maidan uprising in 2013, is also reflected in the imperatives of the »corrupted « mind. It is the fertile ground for breaking up this self-defeating strategy of moral knowledge and learning and developing a new moral compass with civil servants of Lviv. By this moral learning in Lviv improves the national-democratic role of the civil servant, improves the legitimacy and trustworthiness of the civic administration, and leads to stronger and more just local political institutions.

The main lesson learned from the Lviv experience is that fighting corruption has to be adjusted to the history and local experience of citizens and civil servants. On the one hand by creating communities of moral inquiry in communities of communal practice. On the other hand by historical institutional analysis, reconstructing the path dependence of experiences with corruption. Being a scholar and practitioner - a street scientist - is, so I argue, crucial in winning the fight against corruption.
\end{abstract}

Keywords: Corruption. Ukraine. Moral learning. Integrity.

\footnotetext{
${ }^{1}$ This essay couldn't have been written without my friends and collegue's Frans Geraedts and Leonard de Jong. The three of us - all philosophers - founded G\&I in 2001 and developped the 'discursive machine' and intervention practice we use. All our thinking is a collaborative philosophical effort. In a deep sense there is only one author. Above that Frans has been my soulmate in Ukraine for ten years know. My gratititude also goes to Orysya Bila my friend, philosopher at the Greek Catholic University, and collegue in G\&I. Without her the reconstruction of the »corrupted « mind as a learning imperative, wouldn't have been possible. Last and not least I want to thank Lviv Mayor Andriy Sadovyy and his staf for inviting us to work inside Lviv City Council in 2007 and being persistent in supporting the project even under very unfavourable circumstances, untill today.
}

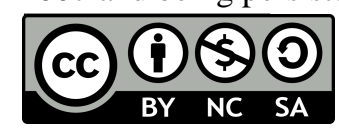

P2P \& INOVAÇÃO, Rio de Janeiro, v. 3 n. 2, p.53-79, Mar./ Set. 2017. 


\section{O SINO DAS MOSCAS}

\section{Resumo}

A luta contra a corrupção é uma questão central no mundo inteiro. O que está em jogo é o direito humano sobre um Estado decente, um Estado de Direito e um governo responsável. Em meu trabalho, me concentro em nossa luta para combater a corrupção em uma das principais cidades da Ucrânia, Lviv. Quero destacar o poder inesperado da aprendizagem moral como uma alavanca crítica para conter a corrupção. Na luta contra a corrupção, faz sentido distinguir entre alto nível e baixo nível, a corrupção de sobrevivência, em russo chamado Blat. A corrupção da sobrevivência requer uma mente "corrompida": uma estratégia de aprendizado moral dos servidores públicos. Esta não é a mente de um funcionário malicioso, ganancioso ou corrupto, mas uma estratégia moral para acomodar a institucionalização política pós-totalitária e oligárquica na Ucrânia. A tragédia da mente "corrompida" é que ela não só ajuda a sobreviver às condições de instituições políticas oligárquicas e corruptas, como também tende a reproduzi-las. Instalar um processo de aprendizado moral para desconstruir a narrativa moral ucraniana, Lviviana, e projetar um discurso moral alternativo com funcionários públicos, parece, portanto, primordial. Com base em seminários sobre aprendizagem moral com cerca de 1500 funcionários públicos em Lviv, reconstruo primeiro esta "corrompida" mente como um conjunto de imperativos de aprendizagem moral organizacional na Câmara Municipal de Lviv. Segundo, mostro que esses imperativos dependem de três momentos críticos de institucionalização política em Lviv: totalitário, oligárquico e nacional-democrático. Na "democracia oligárquica", como se chama a Ucrânia, a experiência com o totalitarismo ainda tem sua influência sobre a mente do funcionário público, embora as instituições políticas totalitárias em si não mais existam. Isso se reflete no raciocínio moral defensivo mostrado na mente "corrompida", que eu chamo de Sino das Moscas. A minuciosa e egoísta moralidade do caminho oligárquico leva apenas a uma maior deslegitimação e erosão da confiança nas instituições políticas na Ucrânia e em Lviv contemporâneas e a um possível aumento da corrupção de nível baixo e alto. Isso torna plausível que romper este feitiço do Sino das Moscas e desenvolver um relato alternativo de aprendizado moral seja crucial para reduzir a corrupção e criar uma administração municipal digna, um Estado de Direito e uma Câmara Municipal responsável. A trajetória nacional-democrática, que remonta à independência ucraniana em 1991, a Revolução Laranja de 2004 e a insurreição de Maidan em 2013, também se reflete nos imperativos da mente "corrompida". É o terreno fértil para quebrar esta estratégia de autoderrota de conhecimento moral e de aprendizagem e desenvolvimento de uma nova bússola moral com os funcionários públicos de Lviv. Nesta aprendizagem moral em Lviv melhora o papel nacional-democrático do funcionário público, melhora a legitimidade e confiabilidade da administração cívica, e leva a instituições políticas locais mais fortes e mais justas. A principal lição aprendida com a experiência de Lviv é que a luta contra a corrupção tem de ser ajustada à história e à experiência local dos cidadãos e funcionários públicos. Por um lado, criando comunidades de investigação moral nas comunidades de prática comunitária. Por outro lado, pela análise histórica institucional, reconstruindo a dependência do caminho das experiências com a corrupção. Ser um estudioso e praticante - um cientista de rua - é, assim argumento, crucial na conquista da luta contra a corrupção.

Palavras-chave: Corrupção. Ucrânia. Apredizagem moral. Integridade.

P2P \& INOVAÇÃO, Rio de Janeiro, v. 3 n. 2, p.53-79, Mar./ Set. 2017. 


\section{Introduction}

It's remarkable and quite an achievement that reducing corruption has become globally a main issue for all citizens of the world. A decent, non corrupt government is, or should be, a human right. It's a gateway to a just and prosperous society. Although a non-corrupt government should be common for all residents on our earth, in fact it isn't. Two-thirds of the world citizens are de facto denied the right of a non corrupt government. ${ }^{2}$

It's an understatement that fighting corruption is the decisive issue for the future of Ukraine. And not only for Ukraine. If we succeed in rolling back corruption it will be an example for Russia and other countries in Europe and the world. Corruption has many faces, many symptoms, and many causes. ${ }^{3}$ I't $^{\prime}$ often seen as a disease that infects the whole tissue of a society. It's main symptoms are inequality of rights and wealth, clientelism, low trust among citizens, and stagnant economic development. In short, it compromises political institutions the state and bureaucracy, rule of law and accountable governance. ${ }^{4}$ In Ukraine we see high level corruption among high placed civil servants, politicians, the judiciary and oligarchs, with a lot of money involved. But we also see widespread low level, pity, survival corruption - in Russian called blat: corruption as 'problem solving' and staying alive. Both systems interconnect and enforce each other.

As corruption has many causes, it has many cures. There is no 'one best way' to roll back corruption. There are also no blue prints. Our world wide track record in reducing corruption is still not very impressive. ${ }^{5}$ It needs institutional redesign, separation of powers, an independent and non-political judiciary, the abolition of impunity. It also needs redesign of the municipal government in Ukraine. Local integrity of government is crucial for the building of

\footnotetext{
2 Transparancy International, founded in 1993, and based in Berlin, started it's famous Corruption Perception Index in 1995. In the latest 2016 index we find Ukraine on rank 131 (of 176, index score 29/100) and Brazil on rank 79 (index score 40/100). The Netherlands takes rank 8 (index score 83). See http://www.transparency.org/research/cpi/

${ }^{3}$ A general and consise overview offers Leslie Holmes, Corruption. A very short introduction. (Oxford: Oxford University Press, 2015). For a historical perspective see Grüne, Slanička (Hrsg.) (2010), Korruption. Historische Annäherungen. Göttingen: Vandenhoeck \& Ruprecht. Engels, Farhmeir, Nützennadel (Hrsg.) (2009), Geld, Geschenke, Politik. München: Oldenbourg. An overview of the indisciplinary study of corruption can be found in Kurer (Hrsg.) (2001), Korruption und Governance aus interdisziplinärer Sicht. Neustadt: Degener. A study of corruption in post-communist Europe is Miller, Grodeland, Koshechkina (2001), A Culture of Corruption. Budapest: Central European University Press.

${ }^{4}$ In this I follow Francis Fukuyama. See his The Origins of Political Order (2011), and Political Order and Poltical Decay (2014).

${ }^{5}$ Compare the Corruption Perception Index at the beginning of the millenium with the most recent version. In 200055 of 90 countries scored below 50 (61\%). In 2016 the figures are 121 of $176(69 \%)$. Brazil index score today is roughly the same as in 2000 (39/40). Ukraine improved from a failed state score in 2000 (19) to a weak state score (29) in 2017. See http://www.transparency.org/research/cpi/
} 
a trustworthy state and bureaucracy, rule of law and accountable government. It takes a city to raise a nation.

In all these issues my colleagues and I are heavily involved in Ukraine for the last decade, especially in Lviv and Chernivtsi. In this essay I want to focus on Lviv and on a particular feature of our approach: installing a process of moral learning in City Councils. Corruption in Ukraine is not only about greed, or about politicians and public servants making a lot of money, by using public resources for private gains. It's not only something 'outside', but also something inside the minds and learning imperatives of Ukrainians living and working in the remnants of a post-totalitarian, oligarchic society. The last five years we experimented with creating communities of moral inquiry in the City Council of Lviv, developing a moral compass with civil servants and managers of these cities, and constructing and deconstructing the Ukrainian moral narrative in the public service. In this essay, I invite you to join me in this fascinating life changing adventure.

I'm planning to do this in three steps. First, I want to prepare the ground and introduce you in some thoughts discussing the idea of the "»corrupted « mind as an imperative of organizational learning under the conditions of oligarchic political institutions. Second, I want to present some empirical findings as outcome of our work with about fifteen hundred civil servants and others in the last five years. It gives us a view inside this imperative, especially on what I call moral defensive routines. Third I want to discuss some thoughts on the institutional background of this »corrupted « mind and why it makes sense to see introducing a process of moral learning as vital for curbing corruption in modernizing countries.

Before continuing, I have to make two notes. First I apologize for using the words »corrupted « mind. It can sound rather offensive for the people I worked with. It's important to stress that I don't want to describe an individual psychological, sinful, condition, but some characteristics of an imperative of moral, and organizational learning. It's, using a concept of Chris Argyris, a moral theory-in-use that permeates all learning in political institutions in Ukraine. I have no words that better fits the mental experience of living for generations under the perverted conditions of totalitarian and oligarchic rule. It not only produces human beings who have to survive in this moral desert. It not only reproduces the cultural prerequisites of a culture of corruption. But it also destroys something inside: it corrupts our personal, human dignity.

Second a word on the title: the Bell of Flies. The metaphor came up at one of our seminars. It describes a phenomenon of the persistence of attitudes of moral learning that persist, even after the conditioning institutional circumstances have been abolished or softened. The »corrupted « 
mind, as an imperative of moral organizational learning, reflects the echo's of living under totalitarian, nazi and soviet rule from 1939 until 1991 - the year of Ukrainian independence and its oligarchic modification under the Kuchma and Yanukovich presidency. Breaking the spell of The Bell of Flies is imperative for fulfilling the promise made when in 1991 the Lenin Boulevard in Lviv was renamed the Svoboda - Freedom - Boulevard.

\section{Preparing the ground}

\subsection{A lesson in corruption}

Let me start with a short story. About ten years ago - so far before Maidan ${ }^{6}$ - we organized on invitation of Krok University in Kyiv - a seminar on moral judgment ${ }^{7}$ for civil servants of all over Ukraine. In the training we investigate decisions which troubled the participants, and on which they were doubtful what the morally right course of action should be. Our question is quite simple: 'What action in the choice under investigation is morally right?' By morally right we mean that the action takes sufficiently into account the rights, interests, and wishes of all who have to bear the burden of your action. This sounds deceivingly simple, and it is. But it is a powerful moral intervention.

One woman - a civil servant, who was part of the group we worked with - came up with an interesting case. She had an unexpected opportunity for a holiday trip with her family to Poland. Unfortunately she had no passport. The trip was in two weeks, but getting a passport would take her at least a month. So, she asked, should I bribe a civil servant? I pay a $\$ 100,=$ and I get my passport. Everybody happy. We have our holiday and they have an extra income.

\footnotetext{
${ }^{6}$ Maidan was the civic and democratic uprising which started in November 2013 when than president Viktor Yanukovich refused in the laste minute to sign the Association Agreement with the European Union. It ended in Februari 2014 with the ousting of Yanukovich after the killing of about 100 activists, since than called The Heavenly Hundred. See e.g. Katherina Raabe, Manfred Sapper (Hrsg.) (2015), Testfall Ukraine. Berlin: Surhkamp Verlag. Karl Schlögel (2015), Entscheidung in Kiew. München: Hanser Verlag.

${ }^{7}$ In this seminar on moral judgment civil servants investigate from a moral point of view difficult decisions they had to make in their job. In the first part we discuss the question 'what makes an action morally right'. Of course this is the primary question of moral philosophy during its history of the last 2500 years. We come up with an accurate definition: 'An action is morally right if it takes sufficiently into account the rights, interests an wishes of all who are involved and have to bear the burden of the action.' In the second part of the seminar we investigate some of the sticky decisions employees had to make in their job. By using a fairly simple method of taking several steps of moral inquiry the civil servants learn how, together, they can develop a moral judgment on every decision they have to make on which they may have moral doubts. In doing that they can trust that their judgment will be morally right. In short: the seminar offers a philosophical inquiry in the idea of justice, and a practical method of moral inquiry in difficult and sticky decisions. The premium is that it installs a community of moral inquiry in a community of practice of civil servants in City Councils.
} 
When we asked alle participants - all civil servants - what they would do if they were this lady, they all agreed on one imperative: bribe!

However, after we carefully investigated the case the opinion changed 180 degrees. It was definitely morally wrong to bribe a civil servant. The advantage of a holiday could't prevail over violating the right on a non corrupt decent government of 45 million Ukrainians.

After discussing this case another man came up with a case that looked on face value very similar. It was also about bribing. But in a hospital. His little daughter was very ill. She had high fever and he was very worried. In the hospital he waited for the doctor. Every time when a doctor passed by he asked for help. But nothing happened. Then a doctor came in, and he showed some money, and miraculously the doctor took care of the sick little girl. "So", he asked, "was I morally wrong paying the doctor?"

Again, we investigated the case, asking ourselves what would take sufficiently into account the rights and interests of all who are involved in the case. Surprisingly our conclusion was that bribing the doctor was the morally right thing to do. The care for his young daughter should prevail over the rights of 45 million Ukrainian citizens on a non corrupt, decent state. For me this was one of my most memorable experiences in working in Ukraine, which only then just started. First, I learned very quickly how endemic corruption was spread in Ukraine. Not only because of large sums of money could be gained by it, but because a simple problem could be solved by bribing a civil servant. Corruption is a state of mind. Second, what really surprised me, and which I never give a thought before: there is morally wrong, and morally right corruption. There are reasons that make the act of bribing morally wrong. But also reasons that makes bribing morally right. For a nation in transition from being still a corrupt weak state, to a decent, less corrupt state, this lesson is crucial.

\subsection{Blat: high level and low level corruption}

Let's dig a bit deeper into this surprise. There are a few considerations I want to offer which pave our way to a better understanding of the »corrupted « mind as a learning imperative. It makes sense to distinguish between high level, high prized corruption and low level, survival corruption, in Russian called blat. It's worthwhile to quote Orlando Figes from his The Whisperers at length on blat, because it give us a vivid description of survival corruption. In the third part of this paper, I will come back to this issue. 


\begin{abstract}
"To cope with the problems of supply an 'economy of favors' came into operation through small informal networks of patrons and clients. ... To get anything (a rented room, household goods, a railway ticket, a passport or official papers) requires personal contacts - family and kin, colleagues, friends, or friends of friends. ... In factories and institutions, many goods and institutions were supplied and exchanged on the basis of personal contacts and favors. Soviet propaganda portrayed blat as a form of corruption. ... But most people were ambivalent in their attitude on blat: they recognized that is was not morally right, and certainly not legal, but relied on it, as everybody did, to fulfill their needs and get around a system they new to be unfair. Without blat, it was impossible to live with any comfort. ... As the proverb said: 'One must have, not a hundred roubles, but a hundred friends."'8
\end{abstract}

We can discuss if high level, high prized corruption is a precondition for low level, survival corruption, or if it's the other way around. The safest way to state is that both systems interact. But what we can say, is that it is the social acceptance of low level corruption what makes corruption endemic. In this paper I'm interested in this second type of corruption and the »corrupted « mind as a learning imperative refers to this blat, this survival corruption.

This »corrupted « mind is not the mind of a criminal, or the big crooks of corruption. It reflects the mental models and cognitive maps of common people who have learned to live, work and often survive under the conditions of totalitarianism and oligarchy as forms of pseudolegitimate government and authority. You can share the imperatives of the »corrupted « mind without ever taking or offering a bribe. I understand this »corrupted « mind as a complicated and often contradictory set of values, norms, imperatives and feelings. Put it a little differently: as theories of moral actions, defensive moral reasoning and routines and related fears, moral stress and cognitive disturbance and dissonance.

In general we mean by corruption the distortion of something which we value, or regard as a virtue and which is institutionalized in the our public life's and the tissue of modern societies. In our modern background notion of corruption, starting with the distinction of public institutions and private life's, this political institutionalization refers to bureaucracy, democracy, separation of powers, the rule of law, and the moral consensus ${ }^{9}$ supporting this. We can detect this in the bureaucracy concept of Max Weber. A bureaucracy under legal-rational authority makes it possible to define specific forms of corruption: bribery and extortion as the misuse of the public office for personal gain. Thus, corruption compromises the moral

\footnotetext{
${ }^{8}$ Orlando Figes (2007), The Whisperers. Private Life in Stalin's Russia. London: Penguin, p.172. A recent survey of Lviv City Institute confirmed that 'solving problems' was seen as the primary cause and motivation of low level corruption. (Lviv City Institute (2015), Survey of the staff and sevice users of Lviv City Council. Lviv: LCI)

${ }^{9}$ Samuel Huntington (1967), Political Order in Changing Societies. New Haven: Yale University Press.
} 
consensus of political institutions: the state and bureaucracy rule of law and accountable government.

Contrary to what we often think, a totalitarian or oligarchic 'theory of authority' lacks this type of rational-legal bureaucracy. It is not rational and legal at all. It is even not traditional or charismatic.

Neither totalitarian (governance by terror), nor oligarchic (governance by wealth) ${ }^{10}$ regard the legal-rational form of authority as 'their' form of authority. In accordance with 'political justice'11 we can speak of 'political bureaucracy'. The separation of powers does not exist under totalitarian or oligarchic rule, or exist only in name. In oligarchic logic a political representative is a 'lawmaker', not a representative of 'the people' or 'the citizen'. He represents the oligarch and participates in a fine-grained system of checks-and-balances, bribe and counter-bribe, extortion and counter-extortion. That's why the 'bureaucratic' system is actually completely fake. There is e.g. no effective department of health care. The only properly working department is Finance. ${ }^{12}$ Within this 'learning adapted environment' ${ }^{13}$ the civil servant - literally in Russian robotnik, an employee of the state - had to learn to function, and had to do his job.

\subsection{Agency: inside the »corrupted $«$ mind}

Integrity and corruption require different forms of agency, of self-governance and selfconstitution. ${ }^{14}$ It looks as if totalitarian and oligarchic rule destroys the idea of agency itself. But that's not true. It requires a different kind of agency, of self-constitution and selfgovernance, accommodated to perverted social circumstances. The bottom line is: everyone civil servants and citizens - needs to learn to develop a »corrupted « mind to survive a totalitarian or oligarchic background. It requires what the great Lvivian microbiologist and

\footnotetext{
${ }^{10}$ For the classic study of totalitarianism see Hannah Arendt (1951), The Origins of Totalitarianism. London: Andre Deutsch. For oligarchism see Jeffrey A. Winters (2011), Oligarchy. Cambridge: Cambridge University Press.

${ }^{11}$ The classical study on political justice is Otto Kirchheimer (1961), Political Justice. The Use of Legal Procedure for Political Ends. Princeton: Princeton University Press.

${ }^{12}$ Darden, "Blackmail as a Tool of State Domination: Ukraine Under Kuchma," East European Constitutional Review, Volume 10, Spring/Summer 2001

${ }^{13}$ For the concept learning adapted environment see: Sterelny (2102), The Evolved Apprentice. How Evolution made Humans Unique. Cambridge (Mass.): The MIT Press.

${ }^{14}$ Christine Kosgaard's Self-constitution. Agency, Identity, Integrity (Oxford: Oxford University Press, 2015) was very helpful to make this point. See also from an evolutionary point of view: Kim Sterelny (2001), The Evolution of Agency and Other Essays.
} 
philosopher of science Ludwik Fleck called a 'community and style of thinking'. ${ }^{15}$ In other words: there is a logic of survival corruption. There is even a morality of survival corruption. Living and working in totalitarian or oligarchic political institutions requires a certain moral virtue and reasoning under perverted circumstances. The »corrupted « mind is socially learned behavior. We are no moral dopes. You are born as a sinner, but not with a »corrupted « mind as an imperative of moral learning. There exists a tacit code of conduct of the good the »corrupted « mind. How to deal with the paradox of the written and the unwritten, contradictory laws, threats, and a blackmailing government.

As we learned - and will discuss below - there are also virtues - or competences - of the skilled »corrupted" mind: 'You don't say what you think; you don't do what you say.' Don't trust anyone, except from your inner circle. Create an inner circle of friends and relations to help you to solve your problems. Pretend and be good at window dressing. Reason legalistic. Create a split brain to survive moral cognitive dissonance. Ease or destroy you public conscience. Protect yourself against guild and shame. All this reveals a state of mind, of a moral cognitive dissonance, and leads to low self esteem, and (self) humiliation. It's often accompanied by indifference and apathy. And there is the secret toleration of corruption. You don't see no harm. Who cares. The »corrupted « mind as a device of moral, organizational learning, however, not only adapts to the learning adapted environment of post-totalitarian and oligarchic political institutions. But it also generates and reproduces this environment and becomes, against all odds and as an unintended consequence, one of the preconditions, the common ground, the moral consensus, of a corrupted society. It's a tragedy of the uncommons.

\subsection{The destruction of the moral compass.}

Though high level corruption is always a perversion and morally wrong and criminal, low level corruption isn't - as we saw - always morally wrong. Someone who performs a corrupt act, is not necessary a bad human being, and even not always acting morally wrong. What is extinguished, however, is the ability is to act with a view on the public good. It perverts the

\footnotetext{
${ }^{15}$ I especially mention Ludwik Fleck (1896-1961), because he was a Jewish microbiologist and philosopher of science living in Lviv in the first half of the last centrury and surviving the Lvivian ghetto and Nazi concentration camps. In the thirthies he intervened in the debate on philosophy of science, prefiguring the concept of paradigm of Thomas Kuhn. In fact Kuhn refers briefly to Fleck in the Preface of his 'The Structure of Scientific Revolutions' (Chicago: The University of Chicago Press, 1962). It illustrates Lviv as centre of artistic and intellectual development and innovation. See Ludwik Fleck (1935), Enstehung und Entwicklung einer wissenschaftlichen Tatsache. Frankfurt a.M: Suhrkamp. For Lviv: Tarik Cyril Amar (2015), The Paradox of Ukrainian Lviv. Ithaca: Cornell University Press, and Kessler, Driebergen, Van Ruyven and Meij (2015), Lviv, City of Paradoxes.
} 
preconditions of what Avishai Margalit calls the decent society, and forces you to become part of a 'rotten compromise'. ${ }^{16}$ In this sense, it is more venomous. It destroys the trust in the difference between true and false, right and wrong, especially when in comes to 'acting in public'. It compromises you trustworthiness and righteousness.

Totalitarian and oligarchic rule leave the common people in a moral wasteland. Like Hannah Arendt wrote: it destroys 'Gemeinsinn', common sense as the common ground of moral judgment. ${ }^{17}$ Under soviet rule moral judgment in Lviv, had to go under cover, go private. Maybe in families. Maybe in the Greek Catholic church. Maybe in small communities of the clientele. But it should definitely not go public. It's a dissident language. Public language is a language of deceit, of hiding, of whispering, of masks. ${ }^{18}$ "You don't say what you think; you don't do what you say." Low trust is paramount.

Oligarchic rule is even worse. Totalitarian rule can at least pretend to serve some ideal, to be realized in the future. The present is a means to an utopia-to-come and the party its moral agent. That's what justifies your current sacrifice. Oligarchic rule is stripped of this promise of righteousness. It leaves nothing than the 'value of nude cash' (Marx), not based on trust and contract als Weber proves to be the core of capitalism. But on the law that everything can be bought - even, or especially, your soul. It transforms every human relation in a cash machine. It reduces every value to value-of-exchange under conditions of extreme inequality of economic power.

\section{Moral learning}

\subsection{Where to begin?}

Against these background it seems understandable, at least I hope, that deconstructing the »corrupted « mind, and finding new moral common ground - especially in the civil service - makes more than sense. So here is where our seminar moral judgment and the installing of a moral learning process in the City Council of Lviv, as our intervention, comes in. It helps to explain a bit how we work.

\footnotetext{
${ }^{16}$ See Avishai Margalit (1996), The Decent Society (Cambridge (Mass.): Harvard University Press) and On Compromise. And Rotten Compromises. (Princeton: Princeton Unversity Press, 2010).

${ }^{17}$ Hannah Arendt, On Totalitarianism.

${ }^{18}$ Sheila Fitzpatrick (2005), Tear of the Masks. Identity and Imposture in Twentieth-Century Russia. Princeton: Princeton University Press.
} 
- First, our strategy is not pressure from the outside, but change and transform from the inside. We are aiming at organizational change. We try to ally with the city administration, management and employees, and build coalitions of the willing inside the City Council. In Lviv its Mayor, Andriy Sadovyy, and his staff, were and still are the core of this coalition. They invited us to work with them together in this 'mission impossible' to lower corruption in the city, even when oligarchic power under the presidency of Viktor Yanukovich was at its peak between 2010 and 2014.

- Second, there are no short cuts, there are no blue prints. Fighting corruption requires that knowledge and methods developed most of the time in countries of the top 20 Transparency International Index, have to be adjusted to, or even reinvented in, highly corrupt countries. The reality principle (Freud) we are confronted with in Ukraine is that of a post-totalitarian, oligarchic nation. This is part and parcel of the daily live in Lviv. When it comes to the totalitarian experience for instance, Lviv as a borderland city, suffered from two totalitarian regimes, loosing $85 \%$ of it's residents between 1940 and 1950 . When it comes to the oligarchic experience, Lviv itself is not an oligarchic city or region. But its political surroundings, with its epicenter in Kyiv, is. ${ }^{19}$ So every effort to curb corruption has to take into account this path dependence, to use the language of historical institutionalism. The idea that fighting corruption is a copy-paste issue, is planning a failure. The same counts for the time it takes: it's a cross generational issue. ${ }^{20}$

- Third, our Lviv project started already eight years ago. So far for Maidan, in circumstances that made fighting corruption virtually impossible. We had to deal with a low trust society, and with a malfunctioning local bureaucracy. Regularly national 'anti corruption' practices consisted in misusing rules and regulations, introducing fear and punishment, especially by the Prosecutor Office, not to reduce corruption, but extort the city administration. In sum: anti corruption was used to reproduce corruption, controlled by the big oligarchs - president

\footnotetext{
${ }^{19}$ According to Sławomir Matuszak (Oligarchic Democracy, 2012) three oligarchic clans where formed under the Kuchma presidency. The Donetsk clan (Akhmentov, the Hayduk and Kluyev brothers) and the powerbase of the Viktor Yanukovich. The Dnipropretovsk clan (Kolomoyskyi, Lazarenko, Tymoshenko, Pinchuk, Boholyubov). The Kyiv clan (Medvedchuk, the Surkis brothers). It's noteworthy that Lviv is not seen as an oligarchic region. There exists no Lvivian oligarchic clan as the equivalent of the Dontesk, Dnipropretovsk and Kyiv clans. That makes Lviv an attractive laboratory in developing knowlegde and learning and designing and implementing policies for reducing corruption on a city level.

${ }^{20}$ The Lvivian generation born under totalitarian rule understands this. When Putin took Crimea and threathened to invade Ukraine, they were preparing for the armed defensive of Lviv. They begged us to take care that the post 1991 generation should seek shelter in Poland. 'We have this soviet virus. We are already lost. But they are the future. They can save Ukraine.' See Amar (2015) and Kessler, Driebergen, Van Ruyven en Meij (2015).
} 
Yanukovich in top - supported by the Ministry of Finance and executed by the judiciary. As the late Samuel Huntington put it: "(I)n a society where corruption is widespread the passing of strict laws against corruption serves only to multiply the opportunity for corruption." ${ }^{21}$

- In these circumstances, fourth, we, together with the city administration, decided that fighting corruption by enforcing compliance would be counterproductive. It would be a big fish to catch by the powerful political forces, especially from Kyiv. It would lower trust inside the City Council and among civil servants. And it would make the City Council even more vulnerable for extortion and bribing. That's why we proposed to start with a curve ball: install a process of moral learning inside the Lviv City Council. When it comes to fighting corruption moral learning seems hopelessly naive. Who is really corrupt and makes a lot of money, will not be worried at all. He can just go on doing what he always did. But it strengthens the moral capital among civil servants, it helps them to stop whispering, share cases and stories, and most of all it teaches civil servants that even under oligarchic rule it is possible to determine which line of action is morally right, and which is morally wrong.

- What proved to be of even more importance: we learned how a »corrupted « mind as an imperative of moral learning under post-totalitarian, oligarchic rule works and can be challenged. ${ }^{22}$ In a decade of experiment this was probably the most impressive, and stimulating lesson: learn and study by creating a community of moral inquiry in the community of practice of civil servants. ${ }^{23}$ Not from the outside, but from the inside. Not about civil servants, but with and by civil servants: how does the corruption actually work, in detail? How does a civil servant under oligarchic political institutions think? How does his moral conscience look like? How to help him to strengthen his own, independent moral judgment?

\footnotetext{
${ }^{21}$ Political Change in Changing Societies, p. 62.

22 To be sure: fighting corruption requires far more than a moral learning process in the City Councils. Apart from this moral learning process, it requires a system of preventive and repressive compliance, an anti-corruption and integrity agency inside the City Council, a monitoring civic forum and a coalition of anti-corruption forces inside city council, the civil society and the business society.

${ }^{23}$ For me the work of Chris Argyris was and is invaluable. For the concept of community of inquiry in a community of practice as a devise for intervention, learning and research see especially Action Science. Concepts, Methods and Skills for Research and Intervention, San Francisco: Jossey Bass, 1985. On organizational learning see of course: Argyris, Schön (1996), Organizational Learning II. Theory, Method, and Practice. Reading (Mass.): Addison-Wesley. For and application in the moral domain see Richard P. Nielsen (1996), The Politics of Ethics. Oxford: Oxford University Press. It is noteworhty that Argyris developped his Action Science approach in line with the idea of a critical theory as developed by Jürgen Habermas. (See in Action Science the chapter on Philosophical and Methodological Issues.)
} 


\subsection{Conscience, the Lviv City Council and post-totalitarian, oligarchic political institutions}

Our Ukrainian trainers, and we ourselves - all trained philosophers and consultants in anticorruption and integrity - conducted about a hundred seminars in which we trained civil servants in moral judgment, and investigated real life moral decisions which they faced in there daily work. While the seminars were meant to be a training, from a social science point of view they are also a form of qualitative moral inquiry. It provided us with a wealth of empirical material. On on one hand we learned how the moral mind in Lviv City Council, within the context of post-totalitarian, oligarchic political institutions work, what the moral predicaments of the civil servants are, and which moral defensive routines ${ }^{24}$ they mobilize. We also learned how to challenge these defensive routines, how to design interventions to deconstruct them, and to help civil servants to open up and start making moral judgments for themselves.

Here is an overview of styles of thinking and moral defensive routines which we found prevalent among civil servants of Lviv City Council, and ways to challenge them.

1. On choices: 'We don't make decisions.' A much used argument to avoid independent moral judgment is the claim 'we don't make choices. Our bosses do, or all is arranged by the law.' Trainers challenged this argument successfully: 'Didn't you decide this morning to get to work? Don't you make a decision to obey your boss? If you decide to follow the the law, is't that your decision? The law doesn't make a decision. You do. If not, you could be replaced a machine.'

\footnotetext{
${ }^{24}$ See on defensive routines: Chris Argyris (1990), Overcoming Organizational Defenses. Boston: Allyn and Bacon.
} 
The discovery. Moral defensive routines: challenging the moral narrative

1. On choices: 'We don't make decisions'.

2. On individual responsibility: 'Authorities are responsible.'

3. On mutual reponsibility: 'This is not about me.'

4. On self-esteem: 'We, Ukrainians are no good people.'

5. On Law and legalism: 'It's the law who decides.'

6. On religion: 'Religion will solve our troubles.'

7. On totalitarian mentality: 'The story of the flies.

8. On European values: 'We don't want these European values in our country.'

9. On corruption: 'Corruption is about bad people.'

10. On trust: 'It's alle about salaries.'

11. On organizational education: 'We don't have time to educate employees.'

12. On punishment: 'Punishment of scapegoating.'

13. On the citizen as a client: 'Every request of the citizen has to be fulfilled.'

14. On moral judgement: 'Making a moral choice seems impossible'.

2. On individual responsibility: 'Authorities are responsible.' Trainees often shift responsibility and blame to authorities and leaders. Trainers discuss this by pointing out that we are all responsible for what happens to the country, the city, the department or a team. This year - the year of Maidan -most of them agreed. 'Maidan is a revolution of our dignity. Not the leaders will solve our problems. We need to. We can strengthen our civil society and government by improving our department and Lviv City Council.'

3. On mutual responsibility: 'This is not about me.' Who takes the decision? Typically employees claim: 'This is not about me.' They do that out of fear: fear of the boss, fear of being punished if they consider themselves as part of the decision. Trainers almost therapeutically counter this excuse. 'It's not only he who decides. That's indecent. Bosses are not a separate race. They have the same doubts and fears as you. They think the same. You are mutual responsible: partly (s)he and partly you.' This often surprises employees. It humanizes the bosses.

4. On self-esteem: 'We, Ukrainians are not very good people (especially our leaders.)' Lowering self-esteem is very effective in feeling helpless, powerless an low moral commitment. Trainers help employees by changing this self-perception by introducing a positive language. 'Do you think that you are worse than people of Amsterdam? Not at all wouldn't you say? The difference is the quality of institutions. Building a good institution. That is something we can do.' 
5. On Law and legalism: 'It's the law who decides.' Legalistic thinking comes in many ways. Applying to the law and avoiding thinking for yourself is very deeply ingrained in the moral mentality of employees. Trainers often discuss this as the totalitarian trap. 'Where does the law comes from. God? The leader? Is the law self-fulfilling? It's our totalitarian heritage. I will tell you the secret of totalitarianism. First you separate people. Than you install a vertical hierarchy with the leader as the source of the law of power and terror. Then you make it look as if this comes form eternity. The difference with democracy is that sovereign citizens are the source of the law. You want democracy, don't you?'

6. On religion: 'Religion will solve our troubles?' Religion is an important moral asset in Ukraine. But it is also used as an excuse not to make your own choices. 'Religion can't make the choices for you. What does Jesus say about smoking? About killing yourself? About pleasure, marriage or about computer games? Which chapter of the Bible do we follow? Or which priest in what parish. Dogma counts, but you have to make up your own mind, depending on the situation.'

7. On totalitarian mentality: The Bell of Flies. Countering the remnants of the totalitarian and soviet mentality, which increases feelings of moral helplessness often occurs in the training. Especially by clarifying that totalitarianism is gone, but not the mentality. 'There is an experiment in biology where flies are put under a glass bell for several hours. Of course the flies are flying in circles in the bell. After some time the bell is lifted. But, surprise, the flies keep flying in the same circles. That's how totalitarianism works'. The moral point: you keep acting as a soviet man, whispering, hiding for visibility, avoiding moral responsibility, even if the soviet glass bell is in smithereens.

8. On European values: 'We don't want all these European values in our country.' Often employees are confused about 'the European way'. 'We don't want these European values, like free marriage of homosexuals.' Our trainers reply: 'Ask yourself. Where do you want to go on holiday? Kazakhstan or Belgium? Ask your self why? It's about individual liberty, a decent democracy and government and increasing wealth. How we apply values in our country is our decision.'

9. On corruption: 'Corruption is about bad people. Remove the rotten apples and the problem is solved.' Of course corruption is a regular issue in the trainings. Clarifying the complexity of 
corruption helps employees to understand corruption and their own involvement. A much recurring idea is that corruption is about bad people. Since you're not one of the bad guys, you don't have to change anything.' 'It's possible', so challenge the trainers, 'But don't you think corruption is a problem of a lack of decent structures. Not of people? Consider our small survival corruption (Blat). We don't do that because we are bad. We exchange the only thing we have, social capital, in stead of money, to solve problems and create opportunities for our kids. Breaking away of corruption means that we have to create structures which makes it no longer necessary to bribe someone to be a good parent.'

10. On trust: 'Its all about salaries.' Usually the excuse on corruption is accompanied by the argument that it is 'all about salaries'. As long as pay is low, corruption stays. Again, you can go on with your life and work als usual. Trainers counter this excuse by pointing out 'that's not about salaries, but about attitudes and trust. As long a we keep avoiding our own responsibility, and working on trustworthy relations, money won't do anything.'

11. On organizational education: 'We have no time to educate people.' When discussing with managers failures and bad performance of employees, regularly the 'shifting the blame' argument - 'We have no time to educate people' - comes up. 'If they don't perform well, they have to be punished.' This is an effective way of creating a low trust department. Trainers explain: 'It is unfair not to educate people. This is not honest. If no one teaches them how to perform well, they will fail. You have to be good to clients, and companies, but also to your employees. This is the difference between the Mafia and Lviv City Council. The Mafia takes good care of its 'employees', but not of its 'clients'. In Lviv City Council it's the other way around. Educating employees is the start of a decent organization.'

12. On punishment: Punishment or scapegoating? Punishment and fear of punishment is a recurring theme in the training. Managers often feel that punishment is the only alternative in controlling employees. Trainers discuss with them that they have seen an lot of unfair punishment: 'Wrong people are punished for wrong reasons, like being punished for not performing well or to respond to external pressure. Often it is not punishing, but scapegoating. The whole system is twisted. It creates mistrust and fear, low learning and low performance. Managers are responsible to punish impartially, fair and for good reasons.' 
Let me summarize our findings. The seminars on moral judgment with civil servants offered an insight in a style of thinking and moral strategies of dealing with the predicaments of the post-totalitarian, oligarchic institutional pressure and practices in Lviv City Council and Lviv as a city in transition. ${ }^{25}$ These are the predicaments of transitional justice. We came across a certain attitude and mindset which we called little flattering but not without reason a »corrupted « mind'. The »corrupted « mind is what Chris Argyris calls a pattern of defensive reasoning and a organizational defensive routine. Defensive reasoning and organizational defensive routines are "actions or policies that prevent individuals or segments of the organization from experiencing embarrassment or threat. Simultaneously, they prevent people from identifying and getting rid of the causes of the potential embarrassment or threat. Organizational defensive routines are anti learning, over protective, and self-sealing." Organizational defensive routines are, according to Argyris, not innate, but social learned in acts of organized self-constitution. ${ }^{26}$

The »corrupted « mind as a learning imperative is thus a way of self-constitution and self-governance that not only reflects but also actively generates and maintains these institutional practices. Targeting and challenging this »corrupted « mind, opened up new, sometimes confusing or disturbing, moral experiences and perspectives for participants in the seminars. In that sense the seminars on moral judgment proved to be a specimen of transformative moral learning.

But it also led to new questions. For instance, I had always seen the civil servants as the passive victims of these oligarchic institutional practices. But now I began to see them also as vectors. How, I asked myself, do these moral theories-in-use of the »corrupted « mind of the civil servant, contribute and reinforce corruption in Ukraine? And, most important, what is the cure of this moral pathology? In the last part of my paper, I want to contemplate on these questions by shifting the stage from a micro, individual perspective, to a macro, institutional perspective.

\section{The bell of flies}

\footnotetext{
${ }^{25}$ I have tot stress again that Lviv City Council is not itself a specimen of an oligarchic political institution. In stead it is a city in transition, probably the most promising city in Ukraine. But as a city in transition it has to deal with what I call in this paper 'post-totalitarian, oligarchic practices' which permeats every political institution in Ukraine.

${ }^{26}$ Chris Argyris (1990), Overcoming Organizational Defenses. Facilitating Organizational Learning. Boston: Allyn \& Bacon, p. 25. Chris Argyris (1999), The Dilemma of Implementing Controls. In: Chris Argyris (1999), On Organizational Learning. Second Edition. Oxford: Blackwell, p. 188.
} 
The »corrupted « mind as a imperative of moral learning, of course, reveals not so much an individual, personal disorder or moral pathology. It is first of all special a type of agency which makes it possible for civil servants in Lviv to cope with post-totalitarian and oligarchic political institutions - the weak state and bureaucracy, the perverted rule of law and a non accountable government and democracy - and their related practices in a city in transition and a nation that also tries to come to terms with its totalitarian, soviet past. The »corrupted « mind than, first of all is an institutional learning imperative of a nation and city in transition. So what does 'institutional' in this respect mean?

"Institutions are", according to Douglas C. North, "the rules of the game in a society or, more formally, the humanly devised constraints that shape human interaction. Institutional constraints include both what individuals are prohibited from doing and, sometimes, under what conditions some individuals are permitted to undertake certain activities. They are the framework within which human interaction takes place. They consist of formal written rules as well as typically unwritten codes of conduct that underlie and supplement formal rules. An essential part of the functioning of institutions is the costliness of ascertaining violations and the severity of punishment." ${ }^{27}$ In their seminal The Social Construction of Reality, Peter Berger and Thomas Luckmann argue that the construction and legitimacy of institutions is build on language and the use of of a stock of knowledge. They take knowledge very broadly as the 'sum total of "what everybody knows" about a social world, an assemblage of maxims, morals, proverbial nuggets of wisdom, values and beliefs, myths, and so forth. ${ }^{28}$ These 'symbolic universes' are, according to Berger and Luckmann "social products with a history. If one is to understand their meaning, one has to understand the history of their production." 29 Or, as we would say today, their genealogy. This quest for institutional genesis invites us to reconstruct the institutional dimension of the $»$ corrupted « mind as an imperative of moral learning, against the foil of its paths dependence with regard to totalitarian, oligarchic and national-democratic institutionalization in Ukraine. ${ }^{30}$ In this historical game (North) civil servants are no judgmental

\footnotetext{
${ }^{27}$ Douglas C. North (1990), Institutions, Institutional Change and Economic Performance. Cambridge: Cambridge University Press, p. 4.

${ }^{28}$ Peter L. Berger (1966), Thomas Luckmann, The Social Construction of Reality. New York: Anchor Books.

${ }^{29}$ Ibidem, p. 97.

${ }^{30}$ Path dependence refers to the idea that 'outcomes at a 'critical juncture' trigger feedback mechanisms (negative or positive) that reinforce the recurrence of a particular pattern in the future ... Once actors have ventured far down a particular path, they find it very difficult to reverse course ... The 'path not taken' or the political alternatives that were once quite plausible may become irretrievalby lost. 'Path dependence' analysis highlights the role of ... 'historical causation' in which dynamics triggered by an event or process at one point in time reproduces
} 
dopes (Garfinkel). In their moral theories-in-use (Argyris) we find several characteristics which make survival corruption under oligarchic rule plausible, and even 'justified', and hard to fight. In this path dependence we recognize some of the points made in the first part of this paper: the institutional reinforcement by the »corrupted « mind of moral dissonance and low trust (3.1.), the problem of the moral consensus, legitimacy and institutional corruption (3.2.) and The Bell of Flies and path dependence(3.3.) I want to discuss these three issues briefly. In the end they will help us to appreciate and value the process of transformative moral learning as breaking the spell of The Bell of Flies and learning to fly (again).

\subsection{Institutional moral dissonance and low trust}

First we can seen that the »corrupted « mind provokes a split in pseudo-loyalty to the political institutions and the retreat of trust in the sphere of private relations: family, friends and clients. I call this 'institutional moral dissonance'. Under totalitarian - soviet - rule institutions, like a city administration, the judiciary or the police couldn't be trusted. They were dangerous, and many Ukrainian paid dearly by becoming too visible as a arbitrary target of repression. The wisest policy under these threatening circumstances was to stay under the radar and fake loyalty on the one hand and, on the other hand, to create small circles of trust inside and outside the civil service that supports survival, including survival corruption. Institutionalized posttotalitarian and oligarchic practices continue this inheritance, although in a much milder form. The moral strategies of distancing itself form Lviv City Council not only adapts to the institutional moral dissonance, but also reinforces the institutional moral dissonance.

The price of fake-loyalty is low trust. Low trust on the one hand among civil servants. Low trust, on the other hand, of citizens in their City Council. Faking loyalty, not saying what you think, and not doing what you say, making up truths, and white or real lies, undermines trustworthiness and righteousness. You can't put trust in the words of you colleague or the employee you are meeting. A couple of hundred years ago Michiel de Montaigne put this very aptly: "Lying is an accursed vice. We are men, and hold together, only by our word. ... Since mutual understanding is brought about solely by way of words, he who breaks his word betrays human society. It is the only instrument by means of which our wills an thoughts communicate,

themselves, even in the absence of the original event or process." Skocpol, T.; Pierson, P. (2002), 'Historical Institutionalism in Contemporary Political Science'. In I. Katznelson, H.V. Millar (ed.), Political Science: State. New York: W.W. Norton, p. 693-721. 
it is the interpreter of our soul. If it fails us, we have no more hold on each other, no more knowledge of each other. If it deceives us, it breaks up all our relations and dissolves all the bonds of our society." 31

Low trust and strategies of distancing and suspending responsibility as characteristic of the »corrupted « mind as defensive moral reasoning - prohibit civil servants (and citizens) to perceive political institutions like a City Council as 'their' institutions. It also justifies survival corruption as a fair way of dealing with failing institutions. It is very hard under these rules of the game (North) and this institutional logic (Berger \& Luckmann), for political institutions, like City Councils, to become civic institutions: institutions that can rely on a minimal trust of civil servants and citizens. It is also very hard for employees of the state to become civil servants, and for residents to become citizens in the full sense of the word. It requires a leap of faith to overcome the predicaments of low trust. But in this leap of fait one can easy be hurt and disappointed.

\subsection{Legitimacy, moral consensus and institutional corruption}

In his Wirtschaft und Gesellschaft Max Weber made the epochal difference between three pure types of legitimate charismatic, traditional and rational-legal authority. The legitimacy as the commitment of subjects to institutions is never enforced only by threat of violence and sanctions, but requires a degree of voluntary consent. The legitimacy of charismatic authority rests on "the specific and exceptional sanctity, heroism or exemplary character of an individual person, and of the normative patterns or order revealed or ordained by him." A traditional authority is perceived as legitimate as "resting on an established belief in the sanctity of immemorial traditions and the legitimacy of the status of those exercising authority under them." The legitimacy of a legal authority is supported by "a belief in the 'legality' of patterns of normative rules and the right of those elevated to authority under such rules to issue commands." The hard core of each type of authority is the moral consensus (Huntington) which frames their legitimacy: the sanctity of an individual person, the sanctity of immemorial traditions or the legality of patterns of normative rules.

It takes no rocket science to see that a legitimate post-totalitarian, oligarchic political institution - state and bureaucracy, rule of law and accountable government - is something like

\footnotetext{
${ }^{31}$ Montaigne, "Of Liars" and "Of giving the Lie", in Essays (1580-1588), 23, 505. Quoted in Steven Shapin (1994), A Social History of Truth. Chicago: University of Chicago Press.
} 
an oxymoron. However, I think, we can be more precise in our judgment. Richard Scott ${ }^{32}$ discerns three pillars of modern institutions, which each are associated with with three sources and questions of legitimacy. They all three contribute to the moral consensus of of the institution. In the regulative pillar legitimacy rests on enforcing compliance, by coercing to act according to laws and regulations, backed by sanctions and soft or hard violence. In the normative pillar legitimacy rests on morally governed consent with social obligations which are normative enforced. In the cultural cognitive pillar legitimacy depends on mimetic imitation of culturally supported and recognized values.

With this in mind it is not hard to see what's the problem with the legitimacy of posttotalitarian, oligarchic political institutions (state and bureaucracy, rule of law and accountable government). From a regulative point of view we deal with what I earlier called 'political justice'. Laws are often contradictory and are meant to support the oligarchic cause. Sanctions are imposed arbitrarily and should instill fear. On the other hand, from a cultural-cognitive point of view we discovered the outline of the »corrupted « mind as an imperative of organizational learning, which leads only to a superficial recognition and support for the Ukrainian political institutions. The normative pillar remains an unoccupied and empty space, a void, because there simply is no serious moral ground of governance. So, instead of a legitimacy of political institutions, based on a moral consensus, we are faced with a pseudo-legitimacy. An immoral consensus, which perverts the civic trust in political institutions in Ukraine, and governmental organizations in general.

\begin{tabular}{|c|c|c|c|}
\hline & Regulative & Normative & Cultural-cognitive \\
\hline Basis of compliance & Expedience & Social obligation & $\begin{array}{l}\text { Taken for grantedness } \\
\text { Shared understanding }\end{array}$ \\
\hline Basis of order & Regulative rules & Binding expectations & Constitutive schema \\
\hline Mechanisms & Coercive & Normative & Mimetic \\
\hline Logic & Instrumentality & Appropriateness & Orthodoxy \\
\hline Indicators & $\begin{array}{l}\text { Rules } \\
\text { Laws } \\
\text { Sanctions }\end{array}$ & $\begin{array}{l}\text { Certification } \\
\text { Accreditation }\end{array}$ & $\begin{array}{l}\text { Common beliefs } \\
\text { Shared logics of action }\end{array}$ \\
\hline Basis of legitimacy & Legally sanctioned & Morally governed & $\begin{array}{l}\text { Comprehensible } \\
\text { Recognisable } \\
\text { Culturally supported }\end{array}$ \\
\hline
\end{tabular}

Figure 1. Pillars of institutions and legitimacy (Scott 2008, p. 51.)

\footnotetext{
${ }^{32}$ W. Richard Scott (2008), Institutions and Organizations. Ideas and Interests. London: Sage Publications.
} 
Dennis Thompson and Lawrence Lessig coined for this perversion of the moral consensus of political institutions the concept of institutional corruption. ${ }^{33}$ I don't want to discuss the concept here, but only point out a few key points. According to Lessig "institutional corruption is manifest when there is a systemic and strategic influence which is legal, or even currently ethical, that undermines the institution's effectiveness by diverting it from its purpose or weakening its ability to achieve its purpose, including, to the extent relevant to its purpose, weakening either the public's trust in that institution or the institution's inherent trustworthiness." ${ }^{34}$ As we saw 'political justice' actually can make corruptive practices legal; on the other hand, as our passport case demonstrated, civil servants saw initially nothing 'unethical' in bribing a civil servant. 'It's simply normal.'

Pseudo-legitimacy, immoral consensus and institutional corruption not only undermine the effectivity and legitimacy of political institutions in Ukraine. That is serious enough. As Daron Acemoglu and James Robinson show, failed or weak institutions are the main obstacle for becoming a powerful, prosperous and decent nation. ${ }^{35}$ But even more vicious is the deepening circle of mistrust. After all, the core of legitimacy is trust and trustworthiness. Legitimate institutions are trusted institutions. Without trust in public institutions no prosperity and no justice. ${ }^{36}$ 'Trust comes on foot and leaves on horseback', as we say in The Netherlands. Or, as a Lvivian professor in mathematics put it in a Shakespearian way. 'To trust, or not to trust', that's the question.

\subsection{The Bell of Flies}

Which brings me to my last point. How to break this chain of the institutionalized »corrupted « mind, institutional moral dissonance, pseudo legitimacy, immoral consensus, institutional corruption and low trust? The answer is quite simple, but not so obvious: break this vicious chain at its weakest link, the empty space, the void which we discovered in reflecting

\footnotetext{
${ }^{33}$ Dennis W. Thompson (1995), Ethics in Congres. From Individual to Institutional Corruption. Washington: The Brookings Institution. Lawrence Lessig (2013), "Institutional Corruption" defined. Journal of Law, Medicine and Ethics. Fall 2013.

${ }^{34}$ Lessing (2013), p. 2.

${ }^{35}$ Daron Acemoglu, James A. Robinson (2013), Why Nations Fail. The Origins of Power, Prosperity and Poverty. London: Profile Books. Francis Fukuyama made as similar point. See his The Origins of Political Order (2012) and Political Order and Political Decay (2014).

${ }^{36}$ See for the significance of trust Onora O'Neill (2002), A Question of Trust. Cambridge: Cambridge University Press, and Francis Fukuyama (1995), Trust. The Social virtues \& the creation of prosperity. New York: The Free Press.
} 
on the legitimacy of post-totalitarian, oligarchic institutions in Ukraine: the lack of moral judgment.

This might seem a bit over the top. It is hard to see how the improvement of moral judgment and moral awareness of civil servants can change the institutional landscape as long as institutional redesign fails. Indeed, Ukraine needed and still needs constitutional reforms, normal political parties, a new health care system, reform of education, decentralization of power and, first of all, the dismantling and restructuring of the judiciary. Which all comes down to beating the oligarchy. However, as long as the »corrupted « mind still reflects and reproduces the imperatives of the post-totalitarian and oligarchic institutions, as long as we are still in the Bell of Flies, it is hard to see how our vicious chain can be broken.

This Bell of Flies, as mentioned above, reflects a path dependence referring to imperatives of a moral theory-in-use which 'reproduces themselves, even in the absence of the recurrence of the original event or process. ${ }^{137}$ According to Skocpol and Pierson these institutionalized theories of action are the outcomes of paths taken at 'critical junctures' in the history of political institutions. I suggest we can identify several of such junctures in Ukraines' history, but I want to pinpoint three ideal types of them, which are relevant for the self-perception, self-constitution and self-governance of the civil servant as a moral agent in Lviv: the totalitarian path, the oligarchic path and the national-democratic path

1. The totalitarian path - the main political actor is the Party. The Party also represents the utopian moral consensus: the promise of a just workers' state, in which private property is abolished. The general, public interest prevails over private, individual rights or interests. The totalitarian experience in Lviv differed from the experience in the eastern part of Ukraine. When the

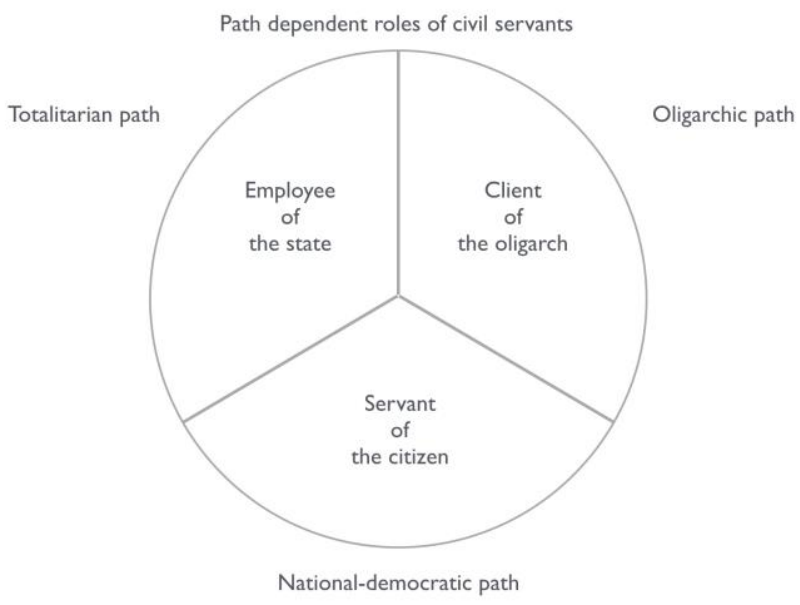
soviet army entered Lviv in 1944 they were not recognized as a liberating, but as an other occupying force. Nevertheless, and despite Lviv's vivid Ukrainian nationalism, the totalitarian, soviet presence dominated the state, the rule of law and governance, and by that

\footnotetext{
${ }^{37}$ See Skocpol \& Pierson, 2002, p. 695-696.
} 
the life and work of civil servants in Lviv until 1991. Due to this path dependence civil servant is an employee of the state.

2. The oligarchic path - the main political actor is the Oligarch. Oligarchy strips of the posttotalitarian political institutions of its already compromised moral consensus. In stead it espouses the liberty, and sustains an 'individuality' of everyone to pursue his own advantage, under the hegemony of the oligarchic institutional imperatives. State and bureaucracy, rule of law and accountable government are bound by the oligarchic interests of gaining, maintaining and protecting wealth. It discredits an independent local government, increases an arbitrary rule of law and robs government of its accountability. A Hobbesian social and political milieu of a 'war of all against all' comes to mind. As I pointed out before, Lviv was never a full blown oligarchic city. There is no Lvivian oligarchic clan. Nevertheless Lviv was dominated by the oligarchic democracy that was forged under the Kuchma presidency and reached it's peak under Yanukovich. Under this circumstances of path dependence the civil servant is the the client of the oligarch and its patrons.

3. The national-democratic path - the core political actor is the Citizen, not as a subject, but as a sovereign. The moral consensus is the liberty and equality of all citizens. The political institutions - the state and bureaucracy, the rule of law and the accountable government reflect this consensus. The city administration provides services and safety for citizens, the rule of law protects their rights and the power of the City Council is checked by democratically elected deputies. On the one hand, Lviv, being part of Habsburgian Europe inherited the democratic European legacy. On the other hand Lviv has been, and still is the centre of Ukrainian national independence in pursuing and protecting the Ukrainian nationstate. Lviv was the centre of the struggle for independence in 1991, the Orange Revolution in 2004 and Maidan in 2013. Al three count as national-democratic uprisings, first against soviet rule and for national independence (1991) and than against the oligarchic democracy, corruption and humiliation. Being part of this critical juncture transforms the Lvivian 'employee of the state' and the 'client of the oligarch' in a civil servant in its trues sense.

These three different paths of dependence are crossing the life and work of Lvivian civil servants and recommend three different types of moral judgment and measures of righteousness. 
- Totalitarian moral judgment - The Parties is the measure of righteousness. An action is just if it is in accordance with the general interest, as represented by the Party. The moral judgment is deductive. The just action is deduced from the policy and prescription dictated by the Party.

- Oligarchic moral judgment - The measure of righteousness is provided by calculating the benefits an action contributes to the wealth of a clientele. An action is just if it optimizes you own interests and that of your clientele. The moral judgment is inductive, in the sense that it rationally calculates costs and benefits for all patrons and clients involved.

- Democratic moral judgment - The measure of righteousness is doing justice to the other. An action is morally right if it takes sufficiently into account the rights, interests and wishes of all who have to bear burden of the action. The moral judgment is reflective, in the sense that is weighs the rights and interests of all who are involved.

From the point of view of the critical junctures and the structure of the related moral judgment I can now clarify the Bell of Flies as a particular configuration of the path dependence of political institutions in Lviv. This configuration is the institutional background of the »corrupted « mind as an imperative of organizational moral learning. The totalitarian path reflects itself in 'the whisperers' - 'Don't say what you think; don't do what you say' - legalistic thinking, avoiding the responsibility for decisions, and shifting them to authorities. The oligarchic path is recognizable in looking for excuses for petty corruption like 'It's all about salaries', 'Everybody does it', and 'Making a moral choice is impossible". The democratic path represents itself in statements like 'Requests of citizens have to be fulfilled' or 'Corruption is about bad people' and 'Corruption is not acceptable'. Skocpol and Pearson underline de value of path dependence' analysis because it "highlights the role of ... 'historical causation' in which dynamics triggered by an event or process at one point in time reproduces themselves, even in the absence of the original event or process." On first sight in seems that the totalitarian roots of the »corrupted « mind are the mental remnants of political institutions which, in their ideal typical sense are no longer in existence, but are occupied by the oligarchic path. In that sense is seems that moral reasoning in accordance with imperatives and the structure of moral judgment of the totalitarian path makes no longer any sense. It is indeed like the flies in the bell who keep flying in circles, even when the bell is lifted. It seems that there is no moral alternative. The oligarchic path certainly is not an attractive alternative. From a moral point of view, it even worsens the case, as we can learn from Samuel Huntington. 
In discussing the scale and incidence of corruption of political institutions Huntington in 1967 makes an interesting remark on corruption in then communist states. The top of the national leadership and the national cabinet are 'comparatively free from corruption'. (68) "The crucial factor in this type of society is the existence of fairly strong national political institutions which socialize rising political leaders into a code of values stressing the public responsibilities of the political leadership." (68) On the other hand the level of corrupt behavior increases as one goes down the political or bureaucratic hierarchy. "Low level bureaucratic officials are more likely to be corrupt than high-level ones; state and local officials are more likely to be corrupt than national ones." (68) This reminds of Blat in the soviet societies, which we discussed above. However, Huntington discusses also societies where the incidence of corruption increases as one goes up the hierarchy. "In terms of frequency as well as scale, national legislators are more corrupt than local officials; cabinet ministers are the most corrupt of all; and the president or top leader is the most corrupt of them all." Such a pattern of 'topheavy corruption' means, according to Huntington, a very low level of political institutionalization. (68) It seems that in Ukraine after 1991 we are witnessing the worst of both sides. On the one hand, the breakdown of the soviet state and the occupying of political institutions by the oligarchy leads to 'top-heavy corruption' at the top leadership. On the other hand, this coincides with the sustained low-level corruption as remnants of soviet political institutions - the state, rule of law and accountable government. Together they produce the pseudo-legitimacy, immoral consensus, low trust and institutional corruption mentioned above, which is reproduced and regenerated by the »corrupted « mind as a set of imperatives of organizational moral learning in political institutions, like Lviv City Council.

Of course, the national-democratic path interrupts the vicious and immoral chain I just sketched. In Lviv this path is powerful, alive and vivid. However, it is understandable that the national-democratic values remain espoused values, instead of values-in-use, if the moral imperatives of the »corrupted « mind remain intact, and without alternative. That makes it plausible that the de- and reconstructing of moral judgment has the potential of becoming a real game changer. It replaces in the civil service the deductive moral reasoning and acting in accordance with the policy of the party, and the inductive moral reasoning and acting in accordance with the interests of the clientele, by the reflective moral reasoning and doing right by the other. Moral learning in Lviv can improve the national-democratic role of the civil servant; improve the legitimacy and trustworthiness of the civic administration, and leads to stronger and more just local political institutions. In a word, it can break the spell of the Bell of Flies. 


\section{Epilogue: Learning to fly... again}

Sometimes you need just some luck. In September 2013, we were rather pessimistic on Ukraines future. President ViktorYanukovich seemed untouchable. Our best hope were the elections of 2015. We, and our Ukrainian friends and colleagues, felt stuck. And then, two months later, as a miracle Maidan - the revolt of dignity - came and changed everything. Suddenly, there was no justification to keep flying in circles in the bell - although the habitualized corrupted flies still found it difficult to make up their own mind. Departments began to declare themselves a 'corruption free area'. Civil servants began to wear buttons 'I can't be bribed'. Making up your own moral mind - filling the moral void - at once didn't seem futile. I think, one of the main lessons learned from our seminars on moral judgment is that, also under less favorable circumstances, deciding what is morally right is possible and increases the moral capital, whatever happens. Though people where often skeptical, they also often perceived this as a revelation and salvation. Breaking down the »corrupted « mind is possible and worthwhile. 'It makes us more open and trustworthy.'

I invited you on a journey, which is still not finished. I really doubt if in my lifetime I will see a corruption free Lviv or Ukraine, which enters the Transparency International Top 50. But I sincerely trust that the Ukrainians will improve and will break the spell of the »corrupted « mind. It's a wonderful experience to see people - young and old - regain their dignity. This is of course not only a history about Lviv and the Lvivians. It's also a history of a middle aged philosopher, a social researcher, working on innovative methods of moral research and intervention. Research which also breaks the spell of soulless, sterile qualitative research which only reproduces what we already know. Research that helps civil servants of Lviv, citizens of Ukraine, even in their darkest hour to learn to fly...again.

\section{Alkmaar}

The Netherlands

March 2017 